\title{
Pendidikan Karakter Melalui Pembelajaran Matematika Menggunakan Catatan Khusus Berkarakter
}

\author{
Prawoto \\ SMAN 1 Kesamben, Kab. Blitar, Indonesia \\ Email: dimasprawoto073@gmail.com
}

\begin{abstract}
Abstrak: Pendidikan karakter belakangan ini menjadi topic yang sering dibicarakan pada ranah pendidikan. Mulai dari pendidikan level dini sampai pendidikan tinggi telah menerapkan pendidikan karakter. Hal tersebut dikarenakan semakin rendahnya karakter orang-orang pada saat ini. Karakter yang buruk menjadi salah satu hal yang harus diatasi guna terciptanya kehidupan yang harmoni. Oleh karena itu, hampir semua mata pelajaran diselipkan pendidikan karakter. Namun, dalam penerapannya sebagian guru termasuk guru matematika masih belum dapat mengendalikan secara baik terutama tentang perilaku siswa. Sehingga penulis bermaksud untu mengupas

Tersedia Online di

http://journal.unublitar.ac.id/pendidika n/index.php/Riset_Konseptual

Sejarah Artikel

Diterima pada : 09-04-2020

Disetuji pada : 29-04-2020

Dipublikasikan pada : 30-04-2020

Kata Kunci:

pendidikan karakter; matematika; catatan khusus berkarakter

DOI:

http://doi.org/10.28926/riset_konseptual.v4i2. 220

penerapan pendidikan karakter pada pembelajaran matematika menggunakan catatan harian berkarakter. Penelitian ini termasuk penelitian konseptual dengan pembahasan yang diambil dari beberapa sumber baik sumber primer maupun sekunder. Dari pembahasan ini dapat disimpulkan bahwa dalam pembelajaran matematika guru dan siswa tidak hanya terpaku pada konten materi yang diajarkan melainkan perlu menanamkan nilai-lai karakter pada siswa. Hal ini dapat dilakukan melalui catatan khusus berkarakter untuk memotivasi siswa dalam berlomba-lomba menerapkan nilai-nilai baik.
\end{abstract}

\section{PENDAHULUAN}

Pendidikan karakter adalah proses pendidikan itu sendiri. Setiap tindakan mendidik selalu memiliki dimensi pembentukan karakter dalam diri siswa (Albertus D. K., 2015a). Namun dalam tindakannya perlu direncanakan untuk menentukan caracara yang efektif bagi program pendidikan karakter dalam kelas agar lebih terarah, karena pendidikan karakter dalam kelas salah satu bagian yang mendukung keberhasilan program karakter di sekolah.

Sebagai guru memiliki kewajiban dalam mendesain, melaksanakan dan mengevaluasi sendiri program pendidikan karakter yang menjadi tugas guru terutama dalam kelas sebagai lokalitas. Seiring pada awal tahun ajaran 2017/2018 SMA Negeri 1 Kesamben kabupaten Blitar memulai dua aksi yang mendapat pengakuan Pemerintah sebagai Sertifikat Aksi Sekolah Bersih Narkoba dari Badan Narkotika Kabupaten Blitar pada 23 Agustus 2017 dan Sertifikat Sekolah Adiwiyata dari Dinas Lingkungan Hidup Kabupaten Blitar pada 25 November 2017. Untuk itu perlu disadari keterpaduan kinerja program pendidikan karakter terutama dimulai dari kelas menjadi sangat diperlukan guna mendukung kedua program tersebut.

Mata pelajaran Matematika cenderung membosankan dan tidak diminati siswa, beberapa hal yang masih terjadi perilaku siswa di kelas saat perlu mendapat perhatian. Perilaku siswa seperti: membuang sampah di bangku kelas, boros energi listrik, budaya charge handphone dan laptop terlalu banyak cabang, keluar pada saat ganti pelajaran duduk di luar dan main handphone, keaktifan dalam mengerjakan Pekerjaan Rumah kurang, saling senyum salam sapa berkurang, mengikis sikap individualis menuju kolektif, menghilangkan mencontek dan kerjasama saat penilaian harian, kerapian seragam yang sesuai ketentuan, kurang memiliki keaktifan dalam belajar 
matematika seperti: menjawab pertanyaan dan mempresentasikan penyelesaian di depan kelas serta sebagai tutor sebaya dalam kelas.

Sebagai guru matematika masih belum dapat mengendalikan secara baik terutama tentang perilaku siswa tanpa berkaitan dengan mata pelajaran dengan buku catatan khusus seperti halnya jurnal mengajar. Buku catatan khusus siswa dapat untuk mencatat siswa yang telah mempresentasikan soal matematika di depan kelas dan menandatangani buku catatan khusus tersebut sebagai catatan positif sebagai perhatian guru, sering kali untuk mencatat hal negatif siswa yang memerlukan tindak lanjut. Catatan khusus siswa menjadi motivasi untuk berlomba mempresentasikan halhal positif ditandai dengan tanda tangan siswa. Oleh karena itu, penelitian ini perlu membahas penerapan pendidikan karakter pada pembelajaran matematika melalui catatan harian berkarakter sebagai salah satu upaya untuk mendorong siswa agar berperilaku sesuai nilai-nilai yang diharapkan.

Setelah melakukan komunikasi dengan beberapa guru, kepala sekolah, pengawas, dan siswa untuk direfleksikan dan dikritisi secara baik dapat disepakati dan menjadi penguatan dan hukuman tercatat dalam Buku Catatan Khusus. Sebagai salah satu Buku Kerja yang wajib dikerjakan guru sesuai instrumen supervisi dari pengawas provinsi. Namun secara menyeluruh aturan sekolah dan tata tertib sekolah belum dapat tercakup dalam buku catatan khusus, karena hanya terbatas pada kelas. Sebagai guru mata pelajaran matematika perlu membuat rancangan pembelajaran yang berbasis penguatan karakter di kelas untuk memberlakukan catatan khusus berkarakter agar unggul, berprestasi, cinta tanah air, kepedulian dengan program sekolah, menjaga lingkungan, taat hukum, dan disiplin sebagai wujud jiwa nasionalisme. Sehingga Artikel gagasan ilmiah ini merupakan metode kajian pustaka dengan mengkaitkan matematika dengan nilai-nilai kemanusiaan.

\section{A. Matematika dan Karakter}

\section{HASIL dan PEMBAHASAN}

Kejadian-kejadian dalam pembelajaran matematika yang akan dicatat dalam buku catatan khusus berkarakter perlu mengenali karakteristik matematika. Setidaknya terdapat delapan cara dalam mendeskripsikan matematika tersebut dalam berbagai aspek kehidupan manusia yaitu: 1) matematika sebagai sistem yang terstruktur (aksiomatis-deduktif); 2) matematika adalah bahasa artifisial/simbolik; 3) matematika adalah cara berpikir; 4) matematika adalah studi mengenai pola; 5) matematika adalah alat; 6) matematika adalah seni; 7) matematika adalah budaya; dan 8) matematika adalah aturan alam semesta (Sumardyono, 2004).

Matematika sebagai ilmu yang aksiomatis-deduktif. Di SMA nampak pada pokok bahasan demensi tiga tentang geometri Euclid ditandai adanya pengertian pangkal dan pernyataan pangkal atau aksioma, lalu muncul pengertian yang perlu didefinisikan dan pernyataan yang perlu dibuktikan. Dalam hal ini karakter yang terkandung dalam pembelajaran matematika harus taat azas atau taat hukum, disiplin, teliti atau cermat, konsisten, dan rasional atau argumentatif (Sumardyono, 2004).

Matematika adalah bahasa artifisial/simbolik sejak awal angka dan variabel sebagai hasil dari generalisasi, abstraksi, yang pada akhirnya menuju pada simbolisasi. Salah satu kekuatan matematika terletak pada aspek bahasa, di mana dengan bahasa simbolik, matematika bisa menjelajah ke area mana pun atau bahasa universal yang sudah disepakati (Pujiadi, 2016). Kode-kode matematika yang mendasarkan pada pengoperasian program komputer dan digitalisasinya. Sehingga pembelajaran matematika dapat menumbuhkan dan menguatkan karakter efisien atau hemat, disiplin, kreatif, dan adaptif (Sumardyono, 2004).

Matematika adalah cara berpikir atau logika berpikir. Orang sering mengatakan berpikir matematis, ini artinya terdapat prinsip-prinsip bagaimana menarik kesimpulan dari berbagai argumen yang valid di dalam matematika. Logika matematika bersifat konsisten. Sehingga pembelajaran matematika dapat menumbuhkan dan menguatkan 
karakter jujur, argumentatif, sistematis, mandiri, demokratis, tanggung jawab, kreatif, kritis, pantang menyerah atau ulet, toleran, dan, rasa ingin tahu (Sumardyono, 2004).

Matematika adalah studi mengenai pola (pattern). Pada saat seseorang bekerja dengan masalah matematika (real-life maupun pure mathematics), sesungguhnya ia menggunakan berbagai pola, mulai dari bentuk (form), rumus (formula), algoritma, cara pemecahan (problem solving strategy), cara memandang masalah matematika, dan seterusnya. Belajar matematika adalah belajar menemukan pola dengan menggunakan pola (yang lain). Menjadi keharusan pembelajaran matematika dapat menumbuhkan dan menguatkan karakter cermat, kritis, kreatif, sistematis, rasa ingin tahu, dan taat azas (Sumardyono, 2004).

Matematika adalah alat (mengenali, mengkonstruksi, dan memecahkan masalah) yang digunakan manusia untuk mengenali alam sekitar dan memecahkan masalah yang timbul. Dengan matematika, manusia dapat mengenali, mengkonstruksi, atau memecahkan masalah dengan lebih sistematis, lebih cepat, lebih akurat, dan lebih mudah. Mulai dari persoalan sederhana tentang panjang dan luas benda hingga masalah kompleks tentang teori kuantum dan alam semesta. Tidak ada konsep matematika yang tidak memiliki aplikasi dalam kehidupan manusia. Menjadi keharusan pembelajaran matematika dapat menumbuhkan dan menguatkan karakter menghargai kegunaan matematika, cermat, mandiri, peduli, dan rasa ingin tahu (Sumardyono, 2004).

Matematika adalah seni yang dirasakan menyenangkan (enjoyful), baik karena keindahan bentuk-bentuk geometris, keindahan pemecahan dengan matematika, keindahan masalah matematika, hingga keindahan cara berpikir matematis. Keindahan juga dapat dirasakan dari masalah-masalah matematika yang memiliki berbagai karakteristik yang menarik. Salah satu di antaranya adalah masalah-masalah yang bentuknya sederhana namun memiliki tingkat kesulitan yang luar biasa, atau sebaliknya, memiliki representasi yang begitu kompleks namun penyelesaiannya begitu sederhana. Keindahan bentuk-bentuk matematis, banyak sekali contohnya. Bentuk fraktal adalah satu satu contoh menakjubkan. Bentuk lainnya adalah gambar pengubinan (tesselasi).

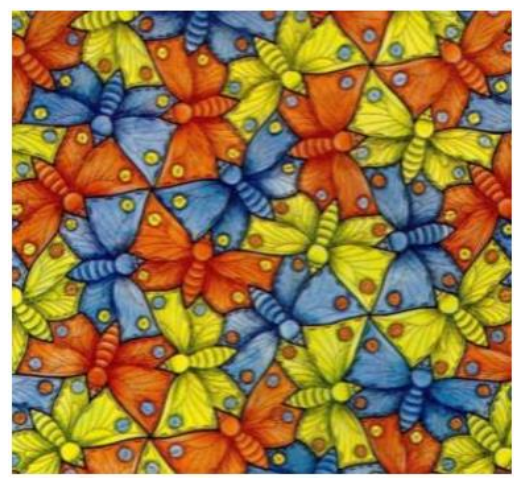

Gambar 1 Pengubinan (sumber: https://i.pinimg.com)

Menjadi keharusan pembelajaran matematika dapat menumbuhkan dan menguatkan karakter kreatif, gigih, cinta damai, toleran, dan, rasa ingin tahu (Sumardyono, 2004).

Matematika adalah budaya yang tidak jatuh dari langit, tetapi lahir dari kesepakatan manusia yang berasal dari pemikiran dan pengalaman hidup. Matematika lahir sebagai bagian dari budaya manusia, seperti halnya teknologi, sistem jual beli, sistem pemerintahan, dan lain sebagainya. Matematika lahir dari berbagai sebab, mulai dari kebutuhan untuk memecahkan masalah sehari-hari, dari ide beberapa orang jenius, dari penemuan tak terduga, dari alam raya, dan sebagainya. Matematika tidak saja memiliki sejarah seperti kebanyakan produk kebudayaan, tetapi juga berevolusi. Sehingga disiplin ilmu ethno-mathematics yang menggunakan aspek budaya ini untuk membantu siswa memahami matematika. Sebagai contoh, masalah matematika dan pembelajaran matematika dapat mengambil konteks budaya Indonesia, misalnya batik, 
satuan ukuran di setiap daerah, bangun bersejarah (misalnya, Borobudur, motif-motif Masjid), permainan tradisional, dan masih banyak lagi. Dengan deskripsi matematika ini, maka seharusnya pembelajaran matematika dapat menumbuhkan dan menguatkan karakter argumentatif, kreatif, kritis, kerja keras, toleran, demokratis, rasa ingin tahu, jujur, peduli, menghargai budaya, dan semangat kebangsaan (Sumardyono, 2004).

Matematika merupakan aturan yang menjadi dasar semua kejadian alam semesta dan dengannya kita memahami alam semesta. Pola yang diperlihatkan oleh alam semesta, manusia dan hewan, serta tumbuhan menggunakan bahasa matematika. Mulai dari bentuk geometri, sifat simetris, fraktal hingga konsep matematika yang tersembunyi pada alam. Contoh barisan Fibonacci $(1,1,2,3,5,8$, $13,21,34,55,89, \ldots$ ) dapat ditemukan misalnya bahwa banyak ruas buah nanas (yang ke kiri, ke kanan, dan ke atas) selalu memenuhi 8, 13, dan 21. Dengan deskripsi matematika ini, maka seharusnya pembelajaran matematika dapat menumbuhkan dan menguatkan karakter ikhlas, jujur, religius, kritis, pantang menyerah atau ulet, peduli, rasa ingin tahu, dan cinta tanah air (Sumardyono, 2004).

Dalam memilih nilai-nilai karakter dapat disesuaikan dengan karakteristik pokok bahasan yang menonjol dan dikembangkan. Penekanan dan penegasan perlu memberikan makna mendalam dari konten materi pelajaran dengan nilai-nilai karakter agar dapat mudah diingat dan dipahami sekaligus dihayati dalam kehidupan seharihari.

\section{B. Integrasi Nilai Karakter Dalam Matematika}

Albertus D.K. (2015a:57) berpendapat:

"Pendidikan karakter dapat diartikan usaha sadar manusia untuk mengembangkan keseluruhan dinamika relasional antarpribadi dengan berbagai macam demensi, baik dari dalam maupun dari luar dirinya, agar pribadi itu semakin dapat menghayati kebebasannya sehingga ia dapat semakin bertanggung jawab atas pertumbuhan dirinya sendiri sebagai pribadi dan perkembangan orang lain dalam hidup mereka berdasarkan nilai-nilai moral yang menghargai kemartabatan manusia".

Beberapa nasehat dari Sathya Sai Narayana tentang pendidikan (Jendra, 2007) sebagai berikut. Pendidikan duniawi membuat manusia menjadi hebat, sedangkan pendidikan spiritual membuat manusia menjadi baik. Pendidikan spiritual berkenaan dengan hati, sebagai sumber sifat-sifat suci seperti belas kasihan, kebenaran, ketabahan, dan kasih sayang. Sekarang ini para orang tua mengharapkan anakanaknya belajar di sekolah yang lebih tinggi, mengumpulkan banyak kekayaan, dan menjadi hebat, tetapi sangat sedikit yang menginginkan anak-anaknya menjadi baik.

Terinspirasi Art-ong Jumsai Na Ayudhya dalam Bukunya berjudul Integration of Human Values in Sciences and Mathematics perlunya memaparkan beberapa ide nilainilai karakter dalam pembelajaran matematika yang harus terus menerus menuangkan nilai-nilai kemanusiaan kepada anak. Berikut ini contoh-contoh yang dapat disampaikan setelah tujuan pembelajaran dikuasai siswa sebagai pemantapan nilainilai karakter.

Selain paparan bernuansa nilai-nilai karakter, guru harus pandai memilih cerita pendek untuk lebih memberikan inspirasi tentang nilai-nilai karakter, bahkan kisahkisah orang besar misalnya Sir Isaac Newton. Beliau mempunyai anjing kesayangan yang diberi nama Diamond dan sangat disayanginya. Pada suatu hari Newton menyelesaikan karya tulis ilmiahnya dalam sebuah naskah dan memutuskan. Diamond melihat tuanya meninggalkan ruangan, melompat mengikuti tuannya namun lilin tersenggol jatuh, dan pekerjaan yang berbulan-bulan ditulisnya dalam naskah terbakar dan musnah. Newton melihat ini, tetapi terlambat untuk menyelamatkan naskah itu. Newton memandang Diamond sejenak. Dia tidak memperlihatkan kemarahan karena sayangnya kepada binatang, Newton berkata perlahan, Diamond, kau tidak akan pernah tahu kenakalan apa telah engkau lakukan hari ini (Ayudhya, 1999). Ceritacerita dengan berbagai kata-kata mutiara tentang nilai-nilai karakter ini dibukukan 
dalam Sejarah Matematika tentang tokoh-tokoh matematika seperti: Plato, Pythagoras, Aristoteles, Euclid, Isaac Newton, Abu Musa Al-Khwarizmi, Ibnu Musa Al-Khwarizmi, Leonardo Pisano Fibonacci, Rene Decartes, Pierre Fermat, Blaise Pascal, Leonhard Euler, Carl Friedrich Gauss, John Napier, de l'Hopital, Lobachevsky, Leibniz, Hipparchus, Nashiruddin Al-Tusi, Jojann Muller, David Hilbert (Sumardyono, 2016). Tokoh-tokoh ini memiliki sejarah atau kisah unik yang menginspirasi pada nilai-nilai karakter dan kata-kata mutiara dan kata bijak tokoh-tokoh matematika dan filsafat.

\section{Guru Menjadi Teladan Karakter Siswa}

Nasehat dari Sathya Sai Narayana tentang keteladanan (Jendra, 2007) bahwa pendidikan yang sesungguhnya adalah pendidikan yang membuat manusia sebagai manusia ideal (teladan). Akhir pendidikan adalah karakter. Jaman dulu guru mereka yang mempraktekkan apa yang dikatakannya. Sekarang guru tidak mempraktekkan apa yang mereka katakan. Guru-guru modern ahli dalam memberikan kotbah di mimbar, sedangkan guru jaman dulu ahli dalam ilmu praktek. Bagaimana bisa siswa menuruti nasehat gurunya, jika sang guru sendiri tidak mempraktekkan apa yang ia katakan? Bila induk sapi merumput di padang rumput, bisakah kita lihat sang anak sapi hanya menonton? Si anak sapi secara alamiah akan mengikuti induknya. Hubungan guru dan siswa haruslah seperti induk dan anak sapi itu. Artinya sang guru haruslah memperlakukan sang siswa seperti anaknya sendiri. Namun, kini kita tidak temukan hubungan yang demikian itu antara guru dan siswa. Keduanya sudah berorientasi pada uang semata. Akibatnya, siswa tidak menghormati guru dan guru tidak memiliki kasih sayang kepada siswanya (Jendra, 2007).

Sebagai contoh yang baik sudah semestinya guru mempraktekkan dahulu. Guru perlu berbicara berdasarkan pengalaman bukan hanya mengulang yang ada di buku atau bahkan hanya membeo atau tidak asal ada Prosedur Operasi Standar (POS) dengan anti dengan teori, budaya instan dan kultur teknis. Setelah mempraktekkan barulah guru mengajar dari hati dan menyentuh hati sang anak. Seperti guru olah raga memperagakan dahulu setelah itu siswa mempraktekkannya. Bagaimanapun nasehat seorang guru memiliki kekuatan luar biasa untuk siswa. Apapun yang dikatakan dan dikerjakan guru, siswa akan merekamnya di dalam pikiran bawah sadarnya, yang akan mempengaruhi siswa di kemudian hari. Guru yang terbaik menginspirasi siswa dan ini tidak pernah terlupakan oleh siswa.

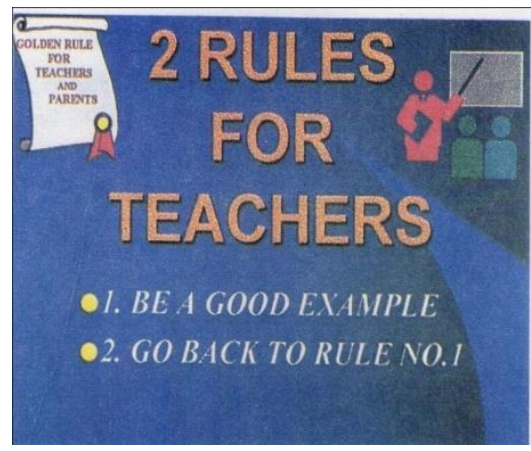

Gambar 2 Dua Peraturan Emas Para guru. Sumber: (Ayudhya, 1999)

Secara mendasar sependapat dengan Dua Peraturan Emas bagi para guru seperti pada gambar 2. Dapat diterjemahkan Dua Peraturan Emas bagi para guru dan orang tua: 1. Jadilah contoh yang baik, 2. Kembali ke Peraturan nomor 1. (Ayudhya, 1999). Betapa setiap langkah guru secara terus menerus tetap menjadi contoh yang baik.

\section{Catatan Khusus Siswa Berkarakter}

Catatan Khusus Siswa Berkarakter sebenarnya seperti halnya jurnal pembelajaran atau catatan anekdotal. Jurnal pembelajaran merupakan catatan di 
dalam dan di luar kelas yang dilakukan oleh guru sendiri berisi hasil pengamatan tentang siswa yang berkaitan dengan sikap dan perilaku, pengetahuan dan keterampilan (Kusaeri, 2014). Catatan anekdotal merupakan catatan informal yang dibuat guru sebagai sumber informasi yang sistematis mengenai perkembangan belajar siswa berupa tindakan, keingintahuan, penghargaan, kebiasaan (Herman dan Yustiana, 2014). Secara lebih khusus catatan khusus siswa berkarakter sebagai catatan evaluasi siswa sekaligus catatan sebagai tambahan penilaian sikap dengan menekankan karakter pada proses belajar mengajar bahkan mencatat tindak lanjut yang sesuai. Format catatan khusus siswa berkarakter seperti pada tabel 1 berikut.

Tabel 1. Catatan Khusus Siswa Berkarakter

\begin{tabular}{|l|l|l|l|l|l|l|l|l|}
\hline $\begin{array}{l}\mathbf{N} \\
\mathbf{0}\end{array}$ & $\begin{array}{l}\text { Hari/ } \\
\text { Tangga } \\
\mathbf{I}\end{array}$ & $\begin{array}{l}\text { Kela } \\
\mathbf{s}\end{array}$ & $\begin{array}{l}\text { Nama } \\
\text { Sisw } \\
\mathbf{a}\end{array}$ & $\begin{array}{l}\text { Nilai } \\
\text { Karakte } \\
\mathbf{r}\end{array}$ & $\begin{array}{l}\text { Kejadia } \\
\mathbf{n}\end{array}$ & $\begin{array}{l}\text { Jumlah } \\
\text { kualitas } \\
\text { partisipa } \\
\text { si }\end{array}$ & $\begin{array}{l}\text { Rencan } \\
\text { a } \\
\text { Tindak } \\
\text { Lanjut }\end{array}$ & $\begin{array}{l}\text { Tanda } \\
\text { tanga } \\
\mathbf{n} \\
\text { siswa }\end{array}$ \\
\hline & & & & & & & \\
\hline
\end{tabular}

karakteristik matematika. Dari penelitian tindakan ternyata setiap yang dilaksanakan siswa sangat bergantung pada model pembelajaran yang dilaksanakan pada saat itu. Keaktifan siswa akan muncul jika terencana dengan baik langkah demi langkah dengan LKS yang disiapkan guru dengan sedikit permainan seperti balap sepeda. Ketepatan reaksi siswa dengan terencana hanya 75 kategori baik (Prawoto, 2017).

\section{E. Tujuan Mata Pelajaran Matematika}

Setidaknya dari delapan deskripsi matematika dapat mengelaborasi karakteristik matematika yang dikaitkan dengan karakter sesuai dengan tujuan mata pelajaran Matematika antara lain:

Tabel 2. Nilai Karakter dari Delapan Diskripsi Matematika

\begin{tabular}{|c|c|c|}
\hline No & Diskripsi Matematika & Nilai-Nilai Karakter yang dikembangkan \\
\hline 1. & $\begin{array}{l}\text { Matematika sebagai sistem } \\
\text { yang terstruktur (aksiomatis- } \\
\text { deduktif }\end{array}$ & $\begin{array}{l}\text { taat azas, atau taat hukum, disiplin, teliti atau } \\
\text { cermat, konsisten, dan rasional atau } \\
\text { argumentatif dan logis }\end{array}$ \\
\hline 2. & $\begin{array}{l}\text { Matematika adalah bahasa } \\
\text { artifisial/simbolik; }\end{array}$ & iplin, kreatif, dan adaptif \\
\hline 3. & $\begin{array}{l}\text { Matematika adalah cara } \\
\text { berpikir; }\end{array}$ & $\begin{array}{l}\text { jujur, argumentatif, sistematis, mandiri, } \\
\text { demokratis, tanggung jawab, kreatif, kritis, } \\
\text { pantang menyerah atau ulet, toleran, dan, rasa } \\
\text { ingin tahu }\end{array}$ \\
\hline 4. & $\begin{array}{l}\text { Matematika adalah studi } \\
\text { mengenai pola; }\end{array}$ & $\begin{array}{l}\text { cermat, kritis, kreatif, sistematis, rasa ingin tahu, } \\
\text { dan taat azas. }\end{array}$ \\
\hline 5. & Matematika adalah alat; & $\begin{array}{l}\text { menghargai kegunaan matematika, cermat, } \\
\text { mandiri, peduli, dan rasa ingin tahu }\end{array}$ \\
\hline 6. & Matematika adalah seni; & $\begin{array}{l}\text { kreatif, gigih, cinta damai, toleran, dan, rasa } \\
\text { ingin tahu. }\end{array}$ \\
\hline 7. & Matematika adalah budaya; & $\begin{array}{l}\text { argumentatif, kreatif, kritis, kerja keras, toleran, } \\
\text { demokratis, rasa ingin tahu, jujur, peduli, } \\
\text { menghargai budaya, dan semangat }\end{array}$ \\
\hline
\end{tabular}




\begin{tabular}{|l|l|l|}
\hline No & \multicolumn{1}{|c|}{ Diskripsi Matematika } & \multicolumn{1}{|c|}{ Nilai-Nilai Karakter yang dikembangkan } \\
\hline 8. & $\begin{array}{l}\text { Matematika adalah aturan } \\
\text { alam semesta. }\end{array}$ & $\begin{array}{l}\text { ikhlas, jujur, religius/spiritualitas, kritis, pantang } \\
\text { menyerah atau ulet, peduli, rasa ingin tahu, dan } \\
\text { cinta tanah air. }\end{array}$ \\
\hline
\end{tabular}

Masalah matematika yang diberikan harus dipecahkan seseorang secara argumentatif dengan jalan pikiran yang logis atau nalar, sehingga dilatih juga untuk bertanggung jawab. Cara berpikir logis yang mendasari kegiatan matematika, juga tidak tunggal, sehingga mengajarkan toleransi. Terakhir, masalah matematika yang menantang (mudah dipahami), dapat memupuk rasa ingin tahu seseorang.

Penemuan pola dalam setiap kegiatan matematika, menghendaki seseorang untuk cermat, berpikir kritis dan kreatif, serta sistematis. Pola yang ia dua atau gunakan harus pula tetap taat pada azas atau hukum (teorema, fakta, aksioma) yang berlaku. Penelusuran pola-pola dalam matematika juga dapat menumbuhkan rasa ingin tahu.

Karakter menghargai kegunaan matematika amat penting untuk ditumbuhkan mengingat pembelajaran yang sebatas penguasaan fakta-fakta matematika telah gagal membuat kebanyakan siswa untuk mencintai dan akrab dengan matematika. Pemilihan masalah yang familiar dan penting untuk dipecahkan dengan matematika, membuat siswa merasakan kegunaan matematika. Dalam kegiatan tersebut, tentu aspek kecermatan diperhatikan, juga dapat memupuk jiwa kemandirian dan peduli (untuk memecahkan masalah nyata, yang mungkin dihadapi setiap orang). Selain itu, aspek kegunaan matematika ini juga memupuk rasa ingin tahu seseorang tentang bagaimana matematika dapat memecahkan masalah nyata.

\section{F. Tindak lanjut Catatan Khusus Siswa Berkarakter}

Selaras deskripsi matematika kaitannya dengan karakter, mata pelajaran matematika antara lain: a) ketelitian dalam menyelesaikan penugasan matematika; b) ketekunan mengikuti pelajaran matematika; c) kegigihan menyelesaikan permasalahan matematika; d) kejujuran dalam menyelesaikan ulangan harian matematika; e) ketepatan waktu menyelesaikan tugas-tugas matematika; f) partisipasi dalam kerja kelompok saat belajar matematika; g) sumbang saran dalam diskusi kelas saat belajar matematika; h) inisiatif bertanya/rasa ingin tahu dalam belajar matematika; dan i) kepercayaan diri dalam menjawab pertanyaan dalam belajar matematika (Hamzah A. , 2014). Memperbaiki afektif siswa terhadap suatu mata pelajaran diharapkan berpengaruh langsung terhadap perbaikan penguasaan kompetensi siswa. Kelas menjadi komunitas belajar yang saling berinteraksi satu sama lain guna menumbuhkan dan mengembangkan, baik secara akademis, moral, kepribadian dan kerohanian. Hanya dengan mengembangkan lingkungan kelas yang ramah, penuh perhatian, memiliki corak relasional yang seimbang dan penuh penghargaan, maka pendidikan karakter berbasis kelas mampu secara efektif menumbuhkan dan mengembangkan pemahaman dan keterampilan moral dari setiap anggota kelas yang ada di dalamnya. Corak relasi antarindividu di dalam kelas adalah khas. Kekhasan tersebut tampil dengan beberapa unsur: obyek pembelajaran, metodologi yang dipakai, serta tata cara evaluasi untuk mengukur keberhasilan sebuah pembelajaran.

Menindaklanjuti setiap kejadian di kelas dikatakan sebagai pelanggaran disiplin sebagai pembiasaan. Poedjawiyatna (1990) dalam (Depdiknas, 2002) pembiasaan berdisiplin diri yang tinggi dengan mematuhi semua peraturan yang ada, atau mematuhi atas dasar suara hati sebagai putusan budi pekerti. Peraturan sekolah merupakan aspek yang harus ada di sekolah dalam upaya pengembangan suasana sekolah yang kondusif. Tata tertib sekolah yang memuat hak, kewajiban, sanksi, 
penghargaan, baik untuk siswa, kepala sekolah, guru dan warga sekolah lainnya (Depdiknas, 2002).

Disiplin sekolah adalah refers to students complying with a code of behavior often known as the school rules. Maksudnya bahwa aturan sekolah (school rule) seperti aturan standart berpakaian (standards of clothing) ketepatan waktu, perilaku sosial, etika belajar. Disiplin sekolah seringkali diterapkan pula untuk memberikan hukuman (sanksi) sebagai konsekuensi dari pelanggaran dari aturan meski kadang kala menjadi kontroversi dalam menerapkan metode pendisiplinannya, sehingga terjebak dalam bentuk kesalahan perlakuan fisik (physical maltreatment) (Gunawan, 2012). Untuk itu guru perlu memahami bentuk-bentuk disiplin positif dalam pendidikan. Guru memahami pengertian dan batasan dan mampu membedakannya dengan hukuman. Guru dapat menganalisa kasus-kasus dalam pendidikan secara umum maupun yang terjadi di sekolah yang berkaitan dengan cara-cara mendisiplin anak/siswa (dengan cara hukuman/negatif atau dengan disiplin positif). Kemampuan guru dalam menerapkan batasan disiplin positif akan meningkat dan hal-hal yang harus dihindari dalam pelaksanaan pendidikan dapat diminimalisir bahkan dihilangkan. Sehingga siswa mampu menginternalisasi proses berpikir dan berperilaku positif dalam jangka waktu yang relatif lama (persistent).

Atas dasar prinsip di atas kriteria disiplin positif yakni: a) Lembut dan baik cara memberikannya; b) Signifikan; c) Merupakan alat yang dapat bekerja dalam waktu yang relatif lama; d) Merupakan keterampilan hidup dan keterampilan sosial yang bermakna bagi anak. Karakteristik alat dan konsep disiplin positif adalah a) Mutual respect antara guru-siswa; b) Mengidentifikasi 'the belief behind the behavior'; c) Komunikasi efektif dan keterampilan memecahkan masalah; d) Disiplin yang mendidik (bukan permissive atau otoriter/hukuman); e) Fokus pada pemecahan masalah bukan hukuman; f) Encouragement: support utk keberhasilan, self esteem dan competency.

Guru harus memberikan kemudahan untuk belajar agar dapat meningkatkan potensi peserta didik secara optimal dengan menempatkan dirinya sebagai: 1) Orang tua yang penuh kasih sayang; 2) Teman bagi siswa; 3) Fasilitator, yang setiap saat memberikan kemudahan; 4) Memberikan sumbangan pemikiran; 5) Memupuk rasa percaya diri dan berani bertanggungjawab; 6) Membiasakan untuk saling berhubungan; 7) Mengembangkan proses sosialisasi; 8) Mengembangkan kreativitas; dan 9) Menjadi mentor ketika diperlukan.

Kesalahan maupun karakter tidak mendidik perlu menjadi perhatian. Kesalahan yang sering dilakukan guru tak berkarakter mulia antara lain: 1) Mengambil jalan pintas pembelajaran; 2) Menunggu peserta didik berperilaku negatif; 3) Menggunakan disiplin distruktif; 4) Mengabaikan perbedaan peserta didik; 5) Tidak adil; dan 6) Memaksa hak peserta didik. Adapun karakter guru yang kurang mendidik antara lain: 1) Memarahi siswa ketika siswa tidak bisa menjawab; 2) Merasa dirinya paling pandai; 3) Menggunakan waktu tidak tepat; 4) Cara mengajar monoton; 5) Diskriminatif; 6) Memberikan penghargaan yang berlebihan; dan 7) Terlalu permisif dengan siswa.

Tindak lanjut mengetahui kemajuan hasil belajar dan kesulitan belajar siswa dengan mengembalikan hasil pemeriksaan pekerjaan siswa disertai balikan/komentar yang mendidik. Komentar yang sifatnya memotivasi untuk meningkatkan pencapaian kompetensi. Contoh: lebih teliti lagi, rumus yang dipilih belum tepat, kerja lebih teliti lagi cara menghitung, belajar lebih giat lagi, bagus, terus pertahankan. Guru tidak menunda pekerjaan mengoreksi pekerjaan siswa (Hamzah A. , 2014). 


\section{KESIMPULAN}

Dari beberapa contoh cara bahwa kita dapat menggunakan matematika untuk mengajarkan Nilai-nilai karakter pada anak. Pekerjaan mempersiapkan pelajaran dan merencanakan perjalanan ke arah kemanusiaan prima tetap menjadi tugas dan tanggung jawab guru dan harus terus-menerus menuangkan nilai-nilai karakter dalam matematika untuk membantu transformasi atau perubahan anak-anak tumbuh dewasa dengan karakter dan kepribadian dan menjadi manusia yang unggul. Salah satu media untuk menanampan nilai-nilai karakter adalah dengan menerapkan catata khusus berkarakter.

\section{DAFTAR RUJUKAN}

Albertus, D. K. (2015a). Pendidikan Karakter Utuh dan Menyeluruh. Yogyakarta: PT Kanisius.

Albertus, D. K. (2015b). Strategi Pendidikan Karakter Revolusi Mental Dalam Lembaga Pendidikan. Yogyakarta: Penerbit PT Kanisius.

Ayudhya, A. O. (1999). Integration of Human values in Sciences and Mathematics. Bangkok: International Institute of Sathya Sai Education.

Depdiknas. (2002). Pedoman Penciptaan Suasana Sekolah yang Kondusif Dalam Rangka Pembudayaan Budi Pekerti Luhur Bagi Warga Sekolah Buku II Cetakan Kedua. Jakarta: Departemen Pendidikan Nasional.

Gunawan, H. (2012). Pendidikan Karakter Konsep dan Implementasi cetakan Kedua. Bandung: CV ALFABETA.

Hamzah, A. (2014). Evaluasi Pembelajaran Siswa. Jakarta: Rajawali Pers.

Hamzah, U. B. (2008). Model Pembelajaran Menciptakan Proses Belajar Mengajar yang kreatif dan Efektif. Jakarta: Bumi Aksara.

Herman dan Yustiana. (2014). Penilaian belajar Siswa di sekolah. Yogyakarta: PT. Kanisius.

Jendra, I. (. (2007). Sabda Sathya Sai Jilid 33. Wacana Sri Sathya sai baba disampaikan tahun 2000. Jakarta: Komite Penerbitan Buku Yayasan Sri Sathya Sai Baba Indonesia.

Kemendikbud. (2013). Materi Pelatihan Kurikulum 2013 SMA/MA SMK/MAK Matematika. Jakarta: Kementerian Pendidikan dan Kebudayaan RI.

Kemendiknas. (2010). Pedoman Kegiatan Pengembangan Keprofesian Berkelanjutan (PKB) Buku 4. Jakarta: Kemendiknas Dirjen Peningkatan Mutu Pendidikan dan Tenaga Kependidikan.

Kemendiknas. (2010). Pendidikan Karakter, Kumpulan Pengalaman Inspiratif. Dalam D. M. Kemendiknas, Memetik Hikmah dari SD Insan Teladan Bogor (hal. 5770). Jakarta: Kemendiknas RI.

Kemendiknas. (2010). Pendidikan Karakter. Kumpulan Pengalaman Inspiratif. Jakarta: Kementerian Pendidikan Nasional.

Kemendiknas. (2011). Panduan Pelaksanaan Pendidikan Karakter. Jakarta: Badan Penelitian dan Pengembangan Pusat Kurikulum dan Perbukuan.

Kusaeri. (2014). Acuan dan Teknik Penilaian Proses dan Hasil Belajar Dalam Kurikulum 2013. Jakarta: Ar-Ruzz Media.

Pujiadi. (2016). Guru Pembelajar Modul Matematika SMA Kelompok Kompetensi H Kurikulum Matematika 2. Jakarta: Kementerian Pendidikan dan Kebudayaan.

Sumardyono. (2004). Karakteristik Matematika dan Implikasinya Pada Pembelajaran. Paket Pembinaan Penataran. Yogyakarta: PPPPTK Matematika.

Sumardyono. (2016). Sejarah dan Filsafat Matematika Untuk Sekolah. Modul Pelatihan. Yogyakarta: PPPPTK Matematika. 